\title{
Ketanserin as potential additive drug to improve V/Q mismatch in COVID-19?
}

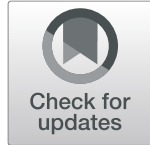

M. Kuindersma ${ }^{1 *}$ (D) and P. E. Spronk ${ }^{1,2}$

Keywords: COVID-19, Coronavirus, Lung, Vasoconstriction, V/Q mismatch

To the editor,

With great interest we read the article by Santamarina et al. [1]. They describe possible underlying causes for the marked ventilation/perfusion $(\mathrm{V} / \mathrm{Q})$ mismatch in patients with COVID-19 while maintaining relatively normal lung compliance. In addition to platelet-fibrin thrombi in the small arterial vessels, they reported evidence of vasoconstriction on CT scans in the relatively unaffected lung parts causing profound V/Q mismatching. They postulate that this vasoconstriction is the effect of increased pulmonary angiotensin II activity with reduced cleavage by ACE-2 due to the SARS-COV2 infection.

In addition to microthrombi and increased angiotensin II activity, the V/Q mismatch may also result from microcirculatory alterations caused by local serotonin-induced arteriolar vasoconstriction. In non-hypoxic circumstances, serotonin can promote $\mathrm{NO}$ release from the endothelium via the $5 \mathrm{HT}_{2 \mathrm{~b}}$ receptor and cause vasodilatation. In contrast, direct activation of smooth muscle cells $\left(5 \mathrm{HT}_{2 \mathrm{a}}\right.$ receptor) may cause vasoconstriction as well in a hypoxic environment. This milieu will induce increased NO consumption by erythrocytes. Consequently, stimulation via the $5 \mathrm{HT}_{2 \mathrm{~b}}$ receptor in the endothelium will not yield further vasodilation due to low NO bioavailability, but will promote vasoconstriction of the smooth muscle tissue [2, 3]. In addition, serotonin secretion might be further increased by platelet activation in COVID-19, thus further

This comment refers to the article available at https://doi.org/10.1186/ s13054-020-03125-9.

* Correspondence: M.kuindersma@gelre.nl

'Department of Intensive Care Medicine, Gelre Hospitals, Albert

Schweitzerlaan 31, Apeldoorn, The Netherlands

Full list of author information is available at the end of the article enhancing microcirculatory vasoconstriction. This sequence of events may worsen the V/Q mismatch and hypoxia in COVID-19.

To improve oxygenation, patients are frequently ventilated in the prone position. The probable effect on oxygenation is an eversion of the vascular redistribution, and not alveolar recruitment. In addition to the relatively simple prone position, pulmonary vasodilators as $\mathrm{NO}$ and prostacyclin have been suggested in severe hypoxemia to improve V/Q mismatch in COVID-19 [4]. Unfortunately, until now, the role of ketanserin has been overlooked. This drug may reverse pulmonary microvascular vasoconstriction without major macrocirculatory effects, provided that adequate resuscitation has been applied [2]. This $5 \mathrm{HT}_{2 \mathrm{a}}$ receptor antagonist can inhibit vasoconstriction by serotonin in COVID-19, which benefits the perfusion of the relatively spared lung parts. In addition, the $5 \mathrm{HT}_{2 \mathrm{a}}$ mediated platelet inhibits aggregation, which inhibits thrombi formation and prevents further serotonin formation [5]. Given the combined effect of ketanserin on pulmonary vasoconstriction and platelet aggregation, it appears to be a valuable additive in the treatment of covid-19 and its use should be further explored.

\section{Acknowledgements \\ Not applicable.}

\section{Authors' contributions}

MK and PES drafted and revised the manuscript. All authors read and approved the final manuscript.

Funding

Not applicable.

Availability of data and materials Not applicable. 
Ethics approval and consent to participate

Not applicable.

\section{Consent for publication}

Not applicable.

\section{Competing interests}

The authors declare that they have no competing interests.

\section{Author details}

${ }^{1}$ Department of Intensive Care Medicine, Gelre Hospitals, Albert Schweitzerlaan 31, Apeldoorn, The Netherlands. ${ }^{2}$ Expertise center for Intensive care Rehabilitation Apeldoorn (ExplRA), Apeldoorn, The Netherlands.

Received: 25 July 2020 Accepted: 17 August 2020

Published online: 28 August 2020

\section{References}

1. Santamarina MG, Boisier D, Contreras R, Baque M, Volpacchio M, Beddings I. COVID-19: a hypothesis regarding the ventilation-perfusion mismatch. Crit Care. 2020;24(1):395.

2. Vellinga NA, Veenstra G, Scorcella C, Koopmans M, van Roon EN, Ince C, et al. Effects of ketanserin on microcirculatory alterations in septic shock: an open-label pilot study. J Crit Care. 2015;30(6):1156-62.

3. Han TH, Qamirani E, Nelson AG, Hyduke DR, Chaudhuri G, Kuo L, et al. Regulation of nitric oxide consumption by hypoxic red blood cells. Proc Natl Acad Sci U S A. 2003;100(21):12504-9.

4. Wu R, Wang L, Kuo HD, et al. An update on current therapeutic drugs treating COVID-19 [published online ahead of print, 2020 May 11]. Curr Pharmacol Rep. 2020;1-15. https://doi.org/10.1007/s40495-020-00216-7.

5. Meuleman TR, Hill DC, Port JD, Stanley TH, Pace NL, Mohammad SF. Ketanserin prevents platelet aggregation and endotoxin-induced pulmonary vasoconstriction. Crit Care Med. 1983;11(8):606-11.

\section{Publisher's Note}

Springer Nature remains neutral with regard to jurisdictional claims in published maps and institutional affiliations. 